\title{
Leituras alemãs de Hamlet, de Goethe a Hegel
}

German Readings of Hamlet, From Goethe to Hegel

\author{
Pedro Süssekind \\ Universidade Federal Fluminense (UFF)
}

\section{RESUMO}

O texto busca apresentar a recepção da célebre peça de Shakespeare em solo alemão, assim como as consequências que essa leitura teve em diferentes momentos do que se convencionou chamar de Goethezeit.

\section{PALAVRAS-CHAVE}

Goethe; Shakespeare; Teatro; Estética.

\section{ABSTRACT}

The text seeks to present the reception of Shakespeare's famous play on German soil, as well as the consequences that this reading had in different moments of what was conventionally called Goethezeit.

\section{KEY WORDS}

Goethe; Shakespeare; Theater; Aesthetics. 
Erich Auerbach, em um capítulo de seu livro Mimesis, de 1946, um dos mais célebres estudos de teoria literária publicados no século vinte, analisa o predomínio da leitura de Hamlet feita por Goethe no final do século dezoito como um modelo para a recepção da peça nas décadas subsequentes. $\mathrm{O}$ crítico considera profunda e bela a "famosa interpretação do Hamlet dada por Goethe", de modo que "com razão não só os românticos, mas também muitos leitores posteriores, na Alemanha e na Inglaterra, admiraram-na” (Auerbach, 1976, p. 293). Aquele predomínio é atribuído à "grande força de convicção na maneira pela qual Goethe explica a tragédia", com base em elementos relevantes na trajetória do protagonista trágico, cujo pai assassinado aparece como fantasma para exigir vingança contra o irmáo que lhe roubou a mulher e a coroa. Entre esses elementos, destacam-se a "súbita ruína da segurança de sua vida exterior e moral da juventude", o "desmoronamento da confiança na ordem ética que era representada para ele, anteriormente, pelo laço, ora tão horrendamente rompido, entre os seus pais, os quais amava e honrava" (Ibid.).

A interpretação que serve como referência para Auerbach ganhou forma sobretudo no romance Os anos de aprendizado de Wilhelm Meister, de I796, que tem como pano de fundo a situação cultural e artística da Alemanha e que descreve com clareza o impacto de Shakespeare nessa situação. Mas consideraçóes sobre o dramaturgo inglês estão registradas também em textos teóricos de Goethe, como o ensaio de I77I "Para o dia de Shakespeare" e especialmente "Shakespeare e o sem fim", publicado em I826. ${ }^{1}$

O jovem autor prestes a escrever o Werther se mostrava, em I77I, um entusiasta incondicional de seu maior ídolo poético: “A primeira página dele que li foi uma identificação por toda a vida, e quando tinha terminado a primeira peça, fiquei como um cego de nascença a quem um gesto milagroso dá, num instante, a visão" (Goethe, 2000, p. 27). Décadas depois, no texto de 1826, o escritor parece bem mais sóbrio e distanciado ao levar em conta sua experiência em adaptar e montar as peças no teatro de Weimar para analisar a obra de Shakespeare enquanto poeta e dramaturgo. Goethe desenvolve uma teoria a respeito das diferenças entre a tragédia antiga (com o predomínio do dever e da necessidade) e a tragédia moderna (na qual imperam a vontade, a subjetividade e a questão da liberdade). Essa teoria pretende encontrar o fundamento pelo qual "nossa arte", como o autor conclui em tom de lamento, permanece irremediavelmente separada da antiga (Ibid., p. 46). ${ }^{2}$ A crítica dirigida à tragédia moderna diz respeito à sua valorização da vontade, do querer, "o deus dos no-

\footnotetext{
1 Cf. Goethe, 2000.

2 Para uma discussão mais abrangente desses textos, cf. meu livro Shakespeare, o gênio original, p. 46.
} 
vos tempos", e não do dever, como ocorria na tragédia clássica. Segundo tal concepção, o dever tornaria a tragédia grande e forte, porque está conectado com a sociedade e com a natureza, e o querer a faria "fraca e pequena", porque eleva acima de tudo o indivíduo. Essa comparação prepara a análise da obra de Shakespeare, autor destacado singularmente por ligar o antigo e o novo de uma maneira exuberante. Em sua obra, Goethe vê um equilíbrio entre o dever e o querer, uma conjugação dos dois termos que ultrapassa o abismo entre a poesia antiga e a moderna.

Um dos exemplos dados em "Shakespeare e o sem fim" para ilustrar a avaliação do dramaturgo é o de Hamlet, peça na qual o conflito interior se expressa na melancolia do protagonista, desde o monólogo inicial, passando por todas as suas hesitaçóes, até o solilóquio mais célebre que tem início com a indagação "Ser ou não ser". No decorrer da ação, ainda no primeiro ato, esse conflito interior de Hamlet seria transformado num dever pelo espírito do rei, que exige vingança. A partir desse momento, a vontade e a necessidade entram em choque. Elas se opóem na forma do dever imposto e da relutância em assumi-lo, adiando a possibilidade de realização do dever e de solução do conflito que expressa o querer (Ibid., p. 45).

Em Os anos de aprendizado de Wilhelm Meister, terminado muitos anos antes desse texto teórico, Goethe já situava nas reflexóes de seu personagem sobre a peça essa noçáo de um conflito entre o dever imposto pelo fantasma do rei e a vontade de Hamlet. Em suas avaliaçóes da tragédia voltadas para uma montagem que faz parte do enredo do romance, Wilhelm Meister chama a atenção para uma certa inadequação do príncipe dinamarquês em relação ao papel de vingador e ao modelo marcial do fantasma de seu pai. Nas conversas com os membros da companhia de teatro, ele descreve o protagonista da peça e sua situação inicial de príncipe herdeiro diante da perda inesperada e prematura de seu pai. Nessa história, "o direito à coroa não era hereditário, e, no entanto, tivesse seu pai uma vida mais longa, haveria consolidado mais as pretensôes de seu único filho e assegurado a esperança da coroa" (Goethe, 1994, p. 243). Agora, excluído do rumo que antes parecia tão consolidado, ele se sentiria "pobre em graça e bens, e alheio àquilo que, desde a infância, considerou como seu patrimônio". Porque aquelas circunstâncias anteriores parecem um "sonho esvaecido", seu caráter toma um rumo triste e nostálgico. As tentativas do tio de animálo na primeira conversa entre os dois são inúteis, ainda mais porque um segundo golpe além da morte do pai o fere mais profundamente ainda: o casamento de sua máe, que deixou rápido demais de ser a viúva enlutada correspondente às expetativas do filho para se entregar a um novo marido. Segundo a avaliação de Goethe, "ela é mulher e, sob a denominaçáo geral do sexo, nela também está implícita a fragilidade”, a inconstância que destrói a confiança de Hamlet na ordem familiar (Ibid.). 
O protagonista da tragédia aparece então aviltado, isolado, nostálgico, sentindose verdadeiramente órfấo. $\mathrm{O}$ encontro com o fantasma, momento decisivo que encerra o primeiro ato da tragédia, deve ser avaliado de acordo com essa disposição de espírito profundamente melancólica que caracteriza Hamlet. Assim, o personagem principal do romance de Goethe descreve o personagem principal da peça de Shakespeare pedindo que se imagine, de modo vivo, o jovem príncipe durante esse encontro ocorrido em uma torre isolada do castelo de Elsinore:

...tenham presente sua situaçáo e entáo o observem bem, a ficar sabendo da apariçáo do espectro de seu pai; ponham-se ao seu lado naquela terrível noite em que também a ele se apresenta o venerável espírito. Um pavor imenso apodera-se dele; interpela aquela forma estranha, vê que lhe faz um sinal, segue-a e a ouve... Ressoam em seus ouvidos a terrível acusaçấo contra seu tio, a exortaçáo à vingança e o premente e reiterado pedido: "Recorda-te de mim!". (Ibid., p. 244)

Em seguida, partindo dessa imagem de alguém tomado pelo terror, Wilhelm Meister especula sobre a figura triste e desamparada que aparece em cena logo após o diálogo e, com isso, quando já está feita a imposição da vingança pela aparição sobrenatural:

E logo que o espírito desaparece, quem vemos diante de nós? Um jovem herói, com sede de vingança? Um príncipe de nascimento, que se sente feliz ao se ver exortado contra o usurpador de sua coroa? Não! Assombro e tristeza assaltam o solitário; ele se torna amargo contra os alegres malfeitores, jura não esquecer o desaparecido e conclui com este suspiro significativo: "Andam desarticulados os tempos; pobre de mim que nasci para pô-los novamente no lugar!". (Ibid.)

Esse trecho aparece no quarto livro do romance de Goethe, depois que o protagonista procura uma companhia teatral e convence seu diretor, Serlo, a montar a peça de Shakespeare na qual ele próprio interpretará o príncipe dinamarquês. Goethe ressalta uma característica essencial do protagonista da tragédia ao chamar a atenção para a figura triste e solitária que resulta do encontro com o fantasma: não "um jovem herói, com sede de vingança", motivado pela tarefa de tirar do trono o usurpador, mas alguém que lamenta sua sorte com a constataçáo de que o tempo está fora do eixo. Essa constataçáo sobre o tempo é avaliada como a chave de toda a conduta de Hamlet (Ibid., p. 244) , $^{3}$ porque anuncia o problema da indecisão ou hesitação do protagonista, que adia ao longo de quatro atos a vingança exigida, até o desfecho

3 Cf. Hamlet, I, 5 (196-197, p. 82) [The time is out of joint: O cursed spite, / That ever I was born to set it right.]. 
trágico. Esse tema problemático recorrente foi abordado e debatido por quase todos que se dispuseram a entender a tragédia de Shakespeare, antes e depois de Goethe.

Friedrich Schlegel, chegou a afirmar em um dos seus Fragmentos sobre poesia e literatura que "Shakespeare é um filósofo romântico" e que "em Hamlet prepondera o romance filosófico" (Schlegel, F., 20I6, p. I83; p. 153). Essas frases demonstram como, desde o final do século dezoito, Shakespeare foi pensado pelos autores românticos como um modelo para definir seu próprio movimento cultural. Hamlet, peça traduzida por August Schlegel em I798, tornou-se um objeto de estudo especialmente relevante nesse contexto. Em seu Estudo sobre a poesia grega, que caracteriza o dramaturgo inglês como uma espécie de Ésquilo moderno, seu irmão Friedrich Schlegel considera essa tragédia como um dos mais importantes documentos da história da estética, e seu protagonista, como a mais perfeita representaçáo da "desarmonia insolúvel" que é o objeto da tragédia filosófica desenvolvida na modernidade (Id., I906, I, p. I07). Em uma de suas preleçóes sobre arte dramática e literatura (I800), August Schlegel, definiria Hamlet como um "drama trágico do pensamento" [Gedankentrauespiel], inspirado por uma meditação contínua sobre o destino humano e "calculado para despertar a mesma meditação nas mentes dos espectadores" . Levando em conta tais consideraçôes, o crítico húngaro Peter Szondi avaliou que a concepçáo da modernidade de Friedrich Schlegel é essencialmente baseada em sua vivência de Hamlet, que parecer ser "um encontro consigo mesmo, uma mirada no espelho" (Szondi, 1974, p. I29).

A recepção imediata de Os anos de aprendizado de Wilhelm Meister foi um marco fundamental para essas reflexôes românticas sobre a tragédia de Shakespeare. Já em 1796, mesmo ano em que o romance de Goethe foi publicado, August Schlegel escreveu uma resenha na qual faz consideraçóes sobre as discussóes a respeito de Hamlet inseridas no enredo. Segundo o crítico, a inserçáo da peça em Os anos de aprendizado náo pode ser encarada de forma alguma como um mero episódio do romance. $\mathrm{O}$ exame e a representação de Hamlet seriam algo como uma "pintura viva para a fantasia” e, ao mesmo tempo, um objeto de profunda reflexão crítica. Ele se surpreendia por encontrar no romance algo de novo e de mais verdadeiro sobre a tragédia, depois de tudo que já tinha sido dito, afinal o caráter do herói shakespea-

${ }^{4}$ O termo usado é “Gedanken-Trauerspiel”. Cf. Schlegel, A. W., I846, S. 248-250. Cf. também Bate, 1992, p. 307. 
riano já tinha ocupado muitas boas cabeças, tinha sido analisado por "valorosos filósofos" e aperfeiçoado pelos "maiores atores dos tempos recentes" (Schlegel, A. W., 2006, p. 87). Esses comentários se encontram no texto "Algumas observaçóes sobre William Shakespeare por ocasião do Wilhelm Meister", que posteriormente se tornou uma das referências para entender a concepção de crítica da literatura que se originou no Romantismo alemão (Ibid., p. 83). ${ }^{5}$

Schlegel, assim como Goethe um estudioso e um entusiasta das obras de Shakespeare, comenta a singular apropriação de uma peça de teatro em uma narrativa ficcional. Como o autor dessa narrativa era também um dos grandes dramaturgos de seu tempo, a apropriação envolve uma discussão profunda sobre a poesia dramática, sobre seus limites e sua relação com um romance. Duas características dos poetas dramáticos são destacadas por Schlegel: a primeira seria a habilidade de captar as sutis manifestaçôes da intimidade de um homem e indicar com exatidão o significado extraído delas; a segunda, a acuidade para dispor essas indicaçôes singulares segundo a verossimilhança em um todo coeso. A criação dramática abrangeria essa habilidade e essa acuidade, mas superaria ambas, constituindo "um maravilhoso olhar que penetra nas almas, diante do qual o invisível se revela visível”, olhar aliado ainda ao "dom de, graças a um poder de visão tão extraordinário, ser capaz de devolver à superfície dos olhos imagens completas e fazer outras aparecerem no espírito, como num claro espelho" (Ibid., p. 85).

A metáfora do espelho serve aqui, de modo específico, para descrever a aproximaçáo entre Shakespeare e Goethe. Assim, segundo os termos do crítico, quando um grande poeta dramático "examina obras de um espírito a ele irmanado", ele não renega sua natureza. Apresentando o que vê, mais do que demonstrando seus pensamentos, ele soube dar uma presença sensível a conceitos muito afastados da sensibilidade, de tal modo que suas consideraçóes se encontram muito mais no campo da arte do que no da teoria. Para Schlegel, o que Goethe faz em Os anos de aprendizado de Wilhelm Meister é, assim, um raro exercício de crítica autêntica, diante dessa tragédia que era ao mesmo tempo a mais admirada e a mais mal compreendida de todas as obras de Shakespeare (Ibid.). Mas as ideias expostas pelo protagonista do romance, em seus esforços para entender a peça e para representar o papel de seu herói no teatro, revelam tanto essa grande capacidade de compreensão crítica do autor, quanto uma projeção, ou uma espécie de espelhamento, entre Wilhelm Meister e Hamlet.

\footnotetext{
5 A crítica começa com a constatação: "Em meio a envolventes atraçóes para espírito, coraçáo e curiosidade, em meio a muitos enigmas lançados aqui e acolá e muitos ensinamentos morais apresentados com seriedade graciosa, Os anos de aprendizado de Wilhelm Meister oferece a todo amigo do teatro, da arte poética dramática e do belo em geral uma dádiva única em seu gênero". Sobre a importância do texto, cf. Benjamin, 1999, p. 75-80.
} 
O herói do romance de Goethe, quando faz sua avaliação do herói da peça, está em um momento decisivo de seu processo de formação, no decorrer do qual ele às vezes fica parado, sem açáo, mas de repente dá passos enormes quando são despertadas nele "forças dormentes" (Ibid., p. 86). A peça que ele avalia, por sua vez, enreda o leitor em consideraçóes labirínticas do seu herói, que permanece em passivo em relação aos incidentes à sua volta. "Feitos são exigidos dele, que devolve apenas sentimentos e pensamentos", como diz Schlegel, mas "mesmo que pouco seja feito, muito acontece, e muito é dado a pensar" (Ibid.). Esse destaque do excesso de pensamento como característica que define o personagem - uma ideia derivada da leitura da peça feita por Goethe - teve grande influência sobre a crítica romântica posterior, e já nas primeiras décadas do século dezenove autores como Coleridge e Hazlitt retomaram diretamente as ideias de Schlegel ao analisar a tragédia de Shakespeare. ${ }^{6}$

Voltando a Auerbach e a sua avaliação crítica da leitura romântica de Hamlet, o título do texto que integra o livro Mimesis é "O príncipe cansado". Ele indica que o autor atribui a Goethe a noção de que Hamlet é um personagem frágil, cujo excesso de reflexão e de sensibilidade explica a hesitação e a incapacidade de agir. Essa compreensão do personagem aparece especialmente naqueles trechos de Os anos de aprendizado de Wilhelm Meister em que o protagonista da história descreve o protagonista da peça. Segundo o diagnóstico de Auerbach, a interpretaçáo proposta por Goethe é, simultaneamente, "também uma imagem estilística do seu próprio tempo, da Goethezeit" (Auerbach, 1976, p. 294). Ou seja, a interpretação revela algo sobre a época em que ela foi feita. Goethezeit [tempo de Goethe] é um termo usado por diversos autores para falar desse período do final do século dezoito e início do dezenove em que surgiram na Alemanha movimentos culturais, artísticos e filosóficos importantes, como o Sturm und Drang, o Romantismo e o Idealismo. O termo foi empregado porque Goethe conviveu com duas geraçôes de artistas e filósofos, participou ativamente dos debates de seu tempo e se tornou uma referência quase incontornável para todos os escritores das geraçóes que o sucederam.

Auerbach resume a interpretação proposta por Goethe de uma maneira que ilustra essa projeção dos valores do intérprete sobre o objeto interpretado: "Hamlet aparece como um jovem terno e sensível, que procura o mais elevado pelo caminho do ideal, modesto e com insuficiente força interior” (Ibid.). A descrição feita nesses

${ }^{6}$ Cf. Bate, 1992, p. 4-6. 
termos poderia ter como base não o protagonista da tragédia de Shakespeare, mas o jovem Werther, o mais famoso personagem goethiano que se tornou quase um arquétipo da personalidade romântica. ${ }^{7}$

Com isso, Auerbach segue uma avaliaçáo que já tinha sido feita antes dele por outros críticos modernistas que, nas primeiras décadas do século vinte, escreveram sobre Hamlet e procuraram rejeitar tanto a leitura romântica quanto a leitura freudiana. ${ }^{8}$ Um exemplo é T. S. Eliot, que em "Hamlet e seus problemas", de I92I, faz uma espécie de metacrítica ao avaliar que muitos críticos antes dele privilegiaram o personagem e não a estrutura da tragédia, o que resultaria em compreensões enganosas. Ele rejeita a interpretação psicológica da peça e, para contestar a leitura romântica, observa que a "mente criativa" de Goethe tinha convertido Hamlet num Werther. ' Também Andrew Bradley, em seu estudo de 1904 sobre a tragédia shakespeariana, criticava a noção romântica, extraída da frase de Goethe, sobre a falta de força e heroísmo que faz Hamlet sucumbir. Esse "jovem tímido e delicado", "uma espécie de Werther", não se parecia nada com o vulto heroico e impressionante que, na tragédia, enfrenta seus companheiros assustados para falar com o fantasma, cria uma armadilha teatral para o rei, mata Polônio, confronta a rainha e duela com Laerte (Bradley, 2009, p. 75). Bradley contesta assim a "visão sentimental" do personagem shakespeariano que fez dele essa figura frágil, meiga e sensível, mas reconhece que, embora o germe dessa ideia talvez pudesse de fato ser encontrado numa expressão usada no Wilhelm Meister, Goethe certamente não era "responsável pela ideia toda” (Ibid., p. 74).

O ensaio "O príncipe cansado" desenvolve uma argumentação semelhante a essa de Bradley ao rechaçar a caracterização de Hamlet como uma figura sensível e sem força. Para Auerbach, por mais que adie a ação decisiva, o protagonista é de longe a figura mais forte da peça, ao redor da qual há uma aura de demonismo que cria respeito, timidez e até medo. Assim, sua hesitação não deveria ser explicada a partir de uma fragilidade de caráter, mas sim da maneira como os acontecimentos que

7 Os sofrimentos do jovem Werther, romance epistolar escrito por Goethe em 1774, foi um sucesso literário sem precedentes naquela época. O livro despertou no público uma reação que foi chamada de febre Werther. Os jovens liam a desventura amorosa do personagem principal com grande fervor, a ponto de imitarem em alguns casos a sua opçáo pelo suicídio (o que acarretou a proibição do romance em algumas cidades, já em I775). Traduzido para outras línguas, o romance tornou seu autor famoso em toda a Europa, e ainda hoje ele continua a ser uma das obras mais conhecidas de toda a história da literatura alemã.

8 Freud também remeteu à leitura de Goethe ao comentar a variedade de explicaçôes de Hamlet, mais de cem anos depois da publicaçáa de Os anos de aprendizado de Wilhelm Meister. O comentário aparece em seu livro A interpretação dos sonhos, de 1900 , com o intuito de apresentar sua própria leitura da tragédia de Shakespeare como um ponto de ruptura em relação às anteriores. Cf. Freud, 20I8, p. 629.

9 Cf. Eliot, 2015, p. 33-39. Curiosamente, o crítico considerava Hamlet, longe de ser uma obra-prima, um "fracasso artístico de Shakespeare", mas sua justificativa desse fracasso com base na ideia de "correlativo relativo" para expressar as emoçóes talvez seja mais problemática e enganosa do que as leituras precedentes. 
despertam o personagem para a vingança acabam por paralisar a sua força de decisão, fazendo do dever de agir um tormento. $\mathrm{O}$ tema é apresentado a partir uma longa pergunta que vale a pena citar integralmente:

Será que Goethe não sentiu a força original e ainda crescente durante a peça de Hamlet, o seu humor cortante, diante do qual recuam todos os que o circundam, a astúcia e a temeridade dos seus ataques, a sua selvagem dureza contra Ofélia, a violência com a qual enfrenta a mãe, a fria calma com que tira do seu caminho os cortesãos que se lhe atravessam, a elástica audácia de todas as suas palavras e de todos os seus pensamentos? (Auerbach, 1976 , p. 294)

Em contraposição à leitura atribuída originalmente a Goethe, Hamlet é avaliado como uma natureza forte na qual a dúvida e o desgosto pela vida são despertados pelas circunstâncias, um personagem ativo, cujo movimento é "rápido, audaz e, por vezes, pérfido, e atinge, com violência certeira, o centro do alvo" (Ibid.).

A ideia, portanto, é contrastar uma nova interpretação da postura de Hamlet àquela leitura que marcou o tempo de Goethe e que poderia ser vista como um esforço para igualar Shakespeare à visão de mundo do final do século dezoito. A um Hamlet que parece semelhante a Werther, Auerbach contrapóe, assim, a percepção desse protagonista astucioso e contraditório que impóem sua força a todos os outros personagens da peça.

Nas primeiras décadas do século dezenove, Hegel já antecipava em certa medida a crítica feita por Auerbach ao destaque quase exclusivo que é dado, na leitura romântica, ao caráter introspectivo e à fragilidade de Hamlet. O filósofo chama a atenção para o fato de que existe um motivo concreto, na tragédia, para a hesitação de Hamlet, de modo que, para além do caráter melancólico e excessivamente reflexivo, deve ser analisada a desconfiança em relação ao fantasma, aparição sobrenatural que revela o crime.

No primeiro volume dos Cursos de estética ministrados a partir de I8I8, Hegel também comenta Hamlet fazendo referência à leitura proposta por Goethe em seu romance. No contexto de um subitem do terceiro capítulo, "O belo artístico ou o ideal”, dedicado à questão da ação, ou mais precisamente dos “indivíduos agentes”, a peça serve para ilustrar a diferença entre a tragédia antiga, que tratava do destino, e a tragédia moderna, que aponta para o tema da liberdade e da vontade. Segue o trecho do curso que começa citando Macbeth: 
... o artista deve principalmente cuidar para que seja preservada para o ser humano a liberdade e a autonomia da decisão. As bruxas de Macbeth, por exemplo, aparecem como forças externas, que predeterminam para Macbeth o seu destino. O que elas proclamam, todavia, é o desejo mais oculto e próprio de Macbeth, que, neste modo aparentemente exterior, chega a ele e se revela para ele. (Hegel, 2000, p. 237)

O fantasma do pai de Hamlet aparece, na sequência, como um segundo exemplo dessa conexão entre o exterior e o interior, entre as forças externas que determinam a ação e a vontade do protagonista trágico. Ao analisar esse exemplo, Hegel desenvolve uma hipótese para explicar a famosa questão da hesitação de Hamlet, retomando aquela interpretaçáo da peça feita por Goethe no Wilhelm Meister. Propondo um contraponto entre o fantasma-guerreiro e o príncipe-intelectual, o filósofo resume a interpretação de seu predecessor: "Hamlet é, porém, uma natureza fraca em termos práticos, um belo ânimo retraído em si mesmo, que dificilmente consegue decidir-se a sair desta harmonia interna" (Ibid.). Trata-se de um personagem "melancólico, pensativo, hipocondríaco e meditativo, e, por isso, não inclinado a um ato rápido”. Desse modo, "tal como também Goethe insistiu na representação que Shakespeare teria querido descrever", o que acontece é que se "impôs um grande ato sobre uma alma que não estava à altura do ato" (Ibid.). Para caracterizar esse protagonista trágico descrito sob a ótica de Goethe, Hegel menciona ainda a metáfora usada no romance: "Aqui será plantado um carvalho em um vaso precioso, que apenas deveria acolher flores lindas em seu seio; as raízes se expandem, o vaso é destruído" (Ibid.).

Com base na caracterização do protagonista ao longo do primeiro ato e no seu diálogo final com o fantasma, o filósofo destaca a conexão que Shakespeare desenvolve entre o pensamento do príncipe e tudo aquilo que o cerca. Com isso, ele desenvolve sua hipótese para explicar a demora de Hamlet em agir: "A aparição do espírito no Hamlet é ainda mais bela e profundamente tratada como uma Forma apenas objetiva do pressentimento interior de Hamlet" (Ibid.). Essa conexáo entre o íntimo do protagonista e a imposição da tarefa seria uma marca do início da peça, pois "vemos Hamlet surgir com o sentimento obscuro de que algo de terrível deve ter acontecido; aparece entâo o espírito de seu pai e lhe desvela todos os delitos". Hegel conjectura então: "Após essa descoberta reveladora esperamos que Hamlet imediatamente puna de modo enérgico os autores do ato e o consideramos completamente legitimado para a vingança. Mas ele vacila e vacila”. Qual seria o motivo dessa hesitaçáo? Seria ela uma falha na estrutura da peça? ${ }^{10}$

\footnotetext{
${ }^{10}$ Segundo o comentário de Hegel a ausência de atividade acarretou recriminaçōes a Shakespeare "porque a peça parecia em parte não querer sair do lugar." Cf. Hegel, 2000, p. 237.
} 
Essas consideraçóes ressaltam o contraste entre a figura militar do pai, associada ao mundo da cavalaria, e o caráter mais moderno do protagonista sobre o qual recai a imposição da vingança. Um guerreiro medieval, homem de ação movido pela honra, é contraposto a essa encarnação do indivíduo renascentista que é o príncipe, um cortesão e estudante, um intelectual cético e melancólico. Esse contraste indica, aliás, uma característica que não se restringe a uma tragédia específica, mas está presente nas peças de Shakespeare de um modo geral: a oposição de personagens impetuosos e ativos a personagens intelectuais e eloquentes. ${ }^{11}$

Em Hamlet, essa oposição é algo que faz parte da estrutura do enredo e está presente desde o início, alegoricamente, no encontro do protagonista com o fantasma de seu pai vestido de armadura, um símbolo dos valores guerreiros tradicionais e, por isso, uma representação daquilo que seu filho não pode ser. A mesma oposição ganha a forma das recriminaçóes dirigidas pelo protagonista a si mesmo, quando aprecia a narração da fúria vingativa de Pirro e inveja a capacidade de se emocionar do ator. Depois disso ainda vêm a somar-se ao fantasma vestido como guerreiro outras figuras de homens de ação que se contrapóem a Hamlet, como Laerte e Fortimbrás.

Entretanto, para além da oposição entre impetuosidade e apatia, também é preciso levar em conta que Hamlet hesita em se vingar por desconfiar explicitamente que o responsável pela revelação do assassinato pode ser um demônio. Ele chega a dizer isso no segundo ato ("O espírito que vi / Talvez seja um demônio, e o demo sabe bem / Assumir formas afáveis”). ${ }^{12}$ Desse modo, após mencionar a metáfora de Wilhelm Meister sobre o vaso frágil que é destruído, Hegel argumenta: "Mas Shakespeare introduz, em relação à aparição do espírito, ainda um traço bem mais profundo. Hamlet vacila porque não acredita às cegas no espírito" (Hegel, 2000, p. 237). Ou seja, o personagem náo é apenas um melancólico diante de uma tarefa pesada demais, ele simplesmente não pode acreditar totalmente nas palavras de um fantasma. Então "vemos aqui que a aparição enquanto tal não dispóe de Hamlet sem resistência, mas ele duvida e quer alcançar a certeza pelos próprios meios, antes de empreender o agir" (Ibid., p. 238).

\footnotetext{
${ }^{11}$ Um dos melhores exemplos da oposiçáo entre a impetuosidade do guerreiro e as reflexốes do intelectual é o drama romano Coriolano. Shakespeare elabora essa oposiçáo em um sentido oposto ao de Hamlet. Como comenta Fernanda Medeiros, após sua conquista militar "durante a qual se comportou como uma verdadeira máquina de guerra" Caio Marcio Coriolano é apresentado como um opositor das palavras vazias da retórica, "nadas agigantados" proferidos pelos oradores em seu louvor a fim de transformar em capital político sua vitória. Essa recusa em participara do jogo político é o que faz o protagonista da peça cair em desgraça. Medeiros propóe uma comparação desse homem de ação anti-retórico com Hamlet, personagem com o maior número de falas de Shakespeare, "que em certo momento de sua história chega a se autocriticar por só saber falar" (Medeiros, 2015, p. 43).

${ }^{12}$ Ato II, Cena 2 (619-62I), p. I07.
} 
No final do primeiro ato, quando o espectro do rei reaparece diante do príncipe e acena para que ele o siga até um lugar isolado, Horácio tenta impedi-lo de seguir o fantasma com a advertência: "Mas se ele o atrair pra dentro do oceano / Ou para o tenebroso cimo do penhasco (...) / Se depois assumir uma forma terrível, / Privando de razão a tua soberania, / Lançando-o na loucura?". ${ }^{13}$ Pouco depois disso, após ouvir o discurso do espectro, Hamlet exclama: "Ó hoste celestial! Ó terra! E o que mais? / Evoco o inferno? Não! Calma, meu coração...”. ${ }^{14}$

As falas evidenciam a ambivalência dessa aparição. No contexto histórico em que foram escritas, elas talvez possam indicar o conflito entre a visão de mundo católica e a protestante, um fator que marcou profundamente a Inglaterra da época de Shakespeare. Alguns estudiosos ligam o espectro à concepção católica, que inclui a ideia do purgatório. Isso porque segundo a concepção protestante um fantasma não poderia ser uma pessoa morta que retorna ao mundo dos vivos, uma vez que não existe o purgatório, apenas o céu e o inferno, para onde as almas são encaminhadas imediatamente. Nesse caso, o espectro náo poderia ser a alma do rei e deveria ser compreendido como uma manifestação demoníaca. A aparição remete, assim, a uma dimensão religiosa problemática naquele período de perseguição e censura aos papistas na Inglaterra. Shakespeare parece fazer uso exatamente dessa ambivalência, e não parece ser à toa que o autor situou os estudos de Hamlet e seus colegas em Wittenberg, cidade alemã onde Lutero pregou as teses que deram origem à reforma protestante. ${ }^{15}$

Hamlet, tragédia na qual a morte aparece como um tema absolutamente decisivo e recorrente começa com uma pergunta dirigida à escuridáo (Bernardo, um dos vigias, diz: "Quem está aî?"), e com uma cena que gira em torno da aparição de um fantasma. No volume IV dos Cursos de Estética, Hegel ressalta a relação do príncipe da Dinamarca com a morte, portanto com a finitude como expressão de uma tragicidade característica do drama moderno. O fantasma seria o símbolo inicial dessa relação, como diz o filósofo ao avaliar o caráter do príncipe da Dinamarca:

As barreiras da finitude não são suficientes para ele; em tal tristeza e docilidade, neste ódio, neste nojo por todos os estados da vida sentimos desde o princípio que ele é um homem perdido neste ambiente terrível, a quem o

\footnotetext{
${ }^{13}$ Ato I, Cena 5 (69-74), p. 74.

${ }^{14}$ Ato I, Cena 5 (92-93), p. 79.

${ }^{15}$ Cf. Nuttall, 2007, p. 205. Para um comentário mais detalhado dessa questão, cf. Greenblatt, 20II, cap. Io (p. 319-329) e 200 .
} 
desgosto interior quase já consumiu antes mesmo de a morte se apresentar para ele do exterior. (Hegel, 2004, p. 270)

A morte que se apresenta do exterior tem a forma do fantasma, uma aparição que corresponde à disposição de espírito extremamente melancólica do príncipe na sua primeira cena no palácio.

Essa consideração sobre a finitude faz parte do terceiro capítulo do volume IV dos Cursos, no qual Hegel analisa a poesia trágica, considerando as diferenças entre as tragédias antigas e as modernas e propondo uma classificação das "espécies da poesia dramática e seus momentos históricos principais" (Ibid., p. 234). Para fazer essa classificação, ele recorda o percurso de sua análise da tragédia como gênero da arte dramática, em três passos: (I) "estabelecemos o princípio da poesia dramática segundo suas determinaçóes universais e particulares"; (2) "vimos que o drama, na medida em que apresenta uma ação fechada em seu desenvolvimento presente, necessita essencialmente de uma exposição completamente sensível"; o terceiro passo seria então verificar como a poesia dramática se separa e espécies particulares, e esse passo se divide por sua vez em três: (I) tragédia, comédia e drama; (2) poesia dramática antiga x moderna; (3) formas concretas que a comédia e a tragédia são capazes de assumir. (Ibid.)

O traço mais fundamental da arte trágica, para Hegel, é a reconciliação. Ele afirma, retomando a definiçáo da tragédia que aparece na Poética de Aristóteles:

Acima do mero temor e da simpatia trágica está, por isso, o sentimento da reconciliação, que a tragédia garante por meio da visão da eterna justiça, que em seu imperar absoluto perpassa a legitimidade relativa dos fins e das paixóes unilaterais, porque ela não pode tolerar que o conflito e a contradição das potências éticas, unas segundo o seu conceito, se imponham vitoriosos na efetividade verdadeira e conquistem consistência. (Ibid., p. 239)

O choque das paixões unilaterais poderia ser identificado em geral nas tragédias de todos os tempos, mas quando trata do "desenvolvimento concreto da poesia dramática e suas espécies” Hegel ressalta a diferença entre a poesia dramática antiga e a moderna. Nas obras gregas, ligadas aos primórdios do gênero dramático, são "o desenlace das potências essenciais da vida e dos deuses que imperam no peito humano", enquanto na "poesia moderna, romântica, ao contrário," o que fornece o objeto privilegiado é "a paixão pessoal, cuja satisfação apenas pode concernir a uma finalidade subjetiva, em geral o destino de um indivíduo e caráter particulares" (Ibid., p. 246). Essa diferença leva o filósofo, mais adiante, à conclusão de que a "tragédia moderna acolhe em seu próprio âmbito, desde o início, o princípio da subjetividade", em outras palavras "na tragédia moderna os indivíduos não agem 
em vista do substancial de seus fins, nem é isso que conserva como o que impulsiona a sua paixão, e sim é a subjetividade de seu coração e ânimo ou a particularidade de seu caráter que buscam satisfação". (Ibid., p. 26I)

Hamlet é citado novamente, neste ponto, justamente para ilustrar essa diferença entre a tragédia antiga e a moderna. Segundo a indicação de Hegel, o enredo de uma tragédia grega que mais se aproxima da situação descrita em Hamlet é o de Coéforas, a segunda peça da trilogia Oréstia, de Ésquilo. Nas duas histórias, resumidamente "o pai e rei foi morto e a mãe casou com o assassino", por isso o filho (Orestes assim como Hamlet) precisa se vingar (Ibid., p. 264). Mas na tragédia de Ésquilo a vingança é imposta pelo deus Apolo por meio de um oráculo. Orestes, criado no exílio, deve retornar à sua cidade natal para matar a mãe, Clitemnestra, e o atual marido dela, Egisto, responsáveis pelo assassinato do rei Agamêmnon cometido na ocasião de seu retorno da guerra de Tróia. Esse assassinato é narrado na primeira peça da trilogia, que leva o nome de Agamêmnon, o pai de Orestes.

Embora não apareça um fantasma em Coéforas, a presença da alma do rei morto ronda toda a peça, que tem início com o filho vingador evocando o pai diante de seu túmulo. Ele é surpreendido pela chegada de escravas que vêm do palácio lideradas por Electra, sua irmã. $\mathrm{O}$ coro das escravas conta que veio trazer oferendas fúnebres a Agamêmnon para apaziguar sua alma, em função de um oráculo que se manifestou durante a noite. Segundo as palavras do coro, "os argutos intérpretes de sonhos, elucidando a vontade dos céus, inspirados por um sopro divino, declaram que o defunto sob a terra externa sem cessar sua amargura e a cólera contra seus assassinos" (Ésquilo, 1990, p. 90).

Essa presença do rei morto exigindo vingança é reforçada ainda pelos juramentos que os dois filhos fazem na cena inicial, dirigindo-se diretamente à alma do pai (Ibid.). No diálogo entre personagens e coro que evoca constantemente o rei morto, Orestes atribui seu retorno do exílio também a uma previsão divina:

Por certo o onipotente oráculo de Apolo / não falhará depois de haver determinado / que eu enfrentasse este perigo até o fim / e revelado em altas vozes afliçôes / que fizeram gelar o sangue no meu peito / se não vingasse um dia a morte de meu pai / punindo os homicidas; o deus ordenou / que eu os exterminasse em retaliaçáo / enfurecido pela perda de meus bens. (Ibid., p. IO2)

Assim, o herói é convocado à vingança como um representante da justiça, do direito patriarcal. Ele precisa eliminar a esposa traidora de Agamêmnon e tirar do trono Egisto, um rei ilegítimo, a fim de apaziguar a alma de seu pai. Se não fizer isso, sofrerá terríveis castigos de Apolo, que o ameaçava com pragas nauseabundas e com o ataque horroroso das Fúrias. 
Com isso, o conflito trágico apresentado por Ésquilo diz respeito a duas dimensóes diferentes da justiça: a lei patriarcal da cidade e a lei matriarcal do sangue. A vingança do príncipe se insere em uma cadeia mais longa de crimes em família, já que Clitemnestra tinha se voltado contra o antigo marido em função do sacrifício de Ifigênia, sua outra filha, cometido por Agamêmnon para apaziguar os deuses e permitir a partida dos navios gregos para a guerra de Tróia. A fim de vingar a morte do pai, cumprindo os desígnios de Apolo, Orestes precisa cometer outro terrível assassinato, encadeando um elo a mais na série de crimes. Entáo o vingador de Coéforas será depois perseguido pelas Fúrias, divindades ligadas aos laços familiares. A última peça da trilogia, chamada Eumênides, apresenta justamente a fuga de Orestes para o templo de Apolo e o julgamento do qual o herói sairá absolvido com a intervençáo da deusa Atena, que vota a seu favor.

Segundo a avaliação de Hegel, esse conflito trágico clássico gira "em torno do fato de que o filho, em sua vingança ética, deve ele mesmo ofender a eticidade" em um outro plano (Hegel, 2004, p. 264). Com isso, o encadeamento das açóes e a sucessáo de crimes de sangue são subordinados a uma instância superior, representada pelas intervençóes de divindades - Apolo, as Fúrias e Atena -, para aplicar a justiça.

O enredo da vingança de um filho é desenvolvido de um modo bastante diferente em Hamlet. Para Hegel, o que na obra grega "tem uma legitimidade ética”, ligada à morte de Agamêmnon, "alcança em Shakespeare, ao contrário, a forma única de um crime infame, no qual a mãe de Hamlet é inocente, de modo que o filho, como vingador, apenas tem de se voltar contra o rei fratricida e nele nada mais vê diante de si que fosse verdadeiramente honrável" (Ibid.).

Por isso, o conflito trágico da peça shakespeariana giraria em torno do caráter subjetivo do protagonista, "cuja alma nobre não foi constituída para esta espécie de atividade enérgica e, cheio de asco pelo mundo e pela vida, jogado de lá para cá entre a resolução, provas e preparativos para a execução, sucumbe devido à própria indecisão e à intriga exterior das circunstâncias" (Ibid.). Essa comparação exemplifica, para Hegel, o diagnóstico já citado de que a tragédia moderna acolhe em seu próprio âmbito, desde o início, o princípio da subjetividade.

Em Hamlet, portanto, o destino do protagonista é ser o vingador do assassinato de seu pai, mas a tarefa imposta pelo fantasma acarreta a ambivalência entre hesitação e atuação, entre inação e impetuosidade. O próprio crime, ao ser revelado pelo fantasma, é encarado como a confirmação de algo que já estava na alma profética do príncipe, por isso como um sinal da desarticulação do tempo que precisa ser reordenado por meio de um novo ato de assassinato. A relação do trágico com a temporalidade, tal como elaborada por Shakespeare nesta tragédia, gira em torno desse tema da morte como consumação das ações apresentadas na tragédia. 
Segundo a frase de Hegel mencionada antes, as barreiras de finitude não eram suficientes para o protagonista, já consumido internamente pelo desgosto muito antes que seu fim chegasse. A relação do trágico com o tempo, tal como elaborada por Shakespeare, desenvolve o tema da morte como consumação implacável de todas as açóes. Conforme observa Bradley, em seu estudo de 1904, nenhuma peça ao final da qual o protagonista esteja vivo é, no sentido shakespeariano, uma tragédia. Já segundo Lukács, numa consideração geral sobre o gênero trágico feita algumas décadas depois, os heróis que morrem na tragédia "já estão mortos antes de morrerem”. Muitos autores que escreveram sobre Hamlet chamam a atenção para esse aspecto de antecipação da morte, entre eles Lacan, que afirmou diretamente, em um seminário da década de 1950: "o drama de Hamlet é o encontro com a morte". ${ }^{16}$

Seguindo uma indicação de Schlegel, a leitura de Hamlet feita por um personagem dentro de um romance diz respeito não só ao conteúdo da tragédia de Shakespeare, mas também à sua forma. Com isso se desenvolve uma reflexão sobre os limites formais dos gêneros poéticos, sobre as relaçôes entre drama e romance na modernidade, sobre uma possível morte da tragédia e um predomínio do romance. Estruturada em torno da suspensão da ação e da apresentação das reflexões e hesitações do protagonista, Hamlet parece pôr em xeque seu próprio gênero literário (drama) e apontar para uma dissolução no gênero literário no qual se encaixam as consideraçôes sobre ela (romance). ${ }^{17} \mathrm{O}$ próprio Goethe aborda diretamente esse assunto quando faz Wilhelm Meister discutir com o diretor e os atores, em meio aos preparativos para a montagem de Hamlet, "qual dos gêneros seria superior: o drama ou o romance" (Goethe, 1994, p. 300).

Vale ressaltar que essa discussão é conduzida por personagens de ficção em uma narrativa que inclui a adaptação de uma peça. $O$ diretor da companhia considera a discussão inútil e equivocada, mas o protagonista não tem uma opiniáo clara sobre o assunto. Com isso, a narrativa passa a apresentar os argumentos teóricos expostos na discussão, inspirados nas categorias da Poética de Aristóteles. Um exemplo é a constatação de que "tanto no romance quanto no drama vemos a natureza e a ação

\footnotetext{
${ }^{16}$ Bradley, 2009, p. 5; Lukács, 20I5, p. 226; Hegel, 2004, p. 270; Lacan, 2016, p. 315.

${ }^{17}$ Devo essa ideia a Marco Aurélio Werle, que a desenvolve em livro ainda inacabado sobre Os anos de aprendizado de Wilhelm Meister. Cf., para um esboço desse desenvolvimento: Werle, 20I3. Vale observar também que a leitura de Goethe neste ponto se aproxima de uma avaliaçáo feita posteriormente pelo crítico romântico Friedrich Schlegel, que enxergou na tragédia de Shakespeare a preponderância do "romance filosófico" (Schlegel, F., 2016, p. I53).
} 
humanas”. A questão é estabelecer a diferença entre os dois gêneros literários, que não se restringe nem à forma exterior, nem ao modo de contar a história, um por narrativa, outro por meio de diálogos (Ibid.). O problema apontado na conversa é que existem dramas que infelizmente não passam de romances dialogados, e romances podem ser escritos sem narrador, por exemplo em uma forma epistolar (como Goethe fez no Werther). Apesar disso, a diferença é estabelecida: o romance deveria apresentar sentimentos e fatos, enquanto os dramas apresentam caracteres e açóes. Por isso, o primeiro gênero, mais descritivo, deveria evoluir lentamente, retardando o avanço da ação para elaborar os sentimentos do protagonista. No segundo há mais pressa, e as açóes são precipitadas pelo caráter do herói. O livre jogo do acaso é considerado, entấo, como algo mais adequando ao romance, porque o drama mostra o destino como imposição aos homens das açôes das quais resulta uma catástrofe.

Essas consideraçóes genéricas, apresentadas como uma conversa, conduzem os personagens de volta a seu objeto preferencial: Hamlet e suas particularidades. Embora se trate de uma obra dramática, eles constatam que o herói curiosamente expressa muitas vezes seus sentimentos e, além disso, é impelido pelos fatos, de modo que a peça tem, na verdade, características de romance (Ibid.). Estruturada em torno da suspensão da ação e da apresentação das reflexôes e hesitaçóes do herói, a peça parece pôr em xeque seu próprio gênero literário (drama) e apontar para uma dissoluçáo no gênero literário em que se encaixam as consideraçóes sobre ela (romance). Desse modo, Goethe se aproxima da avaliaçáo feita posteriormente por Friedrich Schlegel, que enxergou em Hamlet a preponderância do romance filosófico (Schlegel, F., 20I6, p. 153). Apesar disso, segundo a avaliação dos personagens de Os anos de aprendizado, a obra em questáo se mantinha ainda nos limites do tragédia: "Uma vez que o destino traçou seu plano, uma vez que o ponto de partida da peça é uma ação terrível, e o herói é sempre impelido para frente, rumo a uma ação terrível, a peça resulta, portanto, trágica no sentido extremo, e não padece de nenhum outro desenlace senão o trágico" (Goethe, 1994, p. 30I).

Portanto, nesse jogo intertextual, o protagonista de um romance pretende, como parte decisiva de seus anos de aprendizado, entender e representar Hamlet, personagem dramático no qual ele identifica traços romanescos. Goethe reflete assim sobre sua apropriação do drama de Shakespeare, usado como um modelo para o desenvolvimento do caráter de seu personagem.

A fim de esclarecer melhor essa reflexão, cabe lembrar que o livro Os anos de aprendizado de Wilhelm Meister tem um papel decisivo nas grandes teorias do romance desenvolvidas no século vinte. Ele inaugura um gênero novo, chamado de 
"romance de formaçáo", que se caracteriza por apresentar a trajetória de um protagonista, em geral desde a sua infância ou juventude, como um processo de mudança e de aprendizado.

Em suas considerações da década de 1940 sobre "o romance como gênero literário", o crítico russo Mikhail Bakhtin menciona o Wilhelm Meister como uma das obras que suscitaram uma série de avaliaçóes sobre a criação do novo tipo de romance no fim do século dezoito. A conclusão dessa série ocorreria com a teoria do romance elaborada nos cursos de estética de Hegel, filósofo que destaca, entre outras características desse novo tipo de narrativa, a ideia de que o personagem não deve ser apresentado como acabado e imutável, "mas em formação, em mudança, sendo educado pela vida" (Bakhtin, 2019, p. 74). Essa ideia é fundamental para a teoria do romance de Bakhtin, na qual o próprio romance é considerado "o único gênero em formação", por isso capaz de refletir de modo mais profundo e substancial as tendências de formação do mundo moderno. "Só o que está em formação pode compreender a formação", afirma o crítico (Ibid., p. 70-7I).

No livro Goethe e seu tempo, Lukács avaliou Os anos de aprendizado de Wilhelm Meister como "o mais significativo produto de transição da literatura romanesca" na virada do século dezoito para o dezenove. ${ }^{18}$ Mais tarde, no clássico estudo $A$ teoria do romance, de 1965, ele daria a uma parte de seu capítulo sobre a tipologia das formas romanescas o título "Os anos de aprendizado de Wilhelm Meister como tentativa de uma síntese” (Lukács, 2000, p. I38). Sob a ótica dessa teoria, a relação do livro com o teatro pode ser associada ao processo de consolidaçáo do romance como um gênero literário predominante no mundo contemporâneo.

O romance publicado em 1796 é o resultado de uma reelaboraçáo do texto anterior de Goethe, A missão teatral de Wilhelm Meister, de 1785 , no qual o teatro aparecia como ponto culminante da formação do herói. A versão final estende a trajetória do protagonista para além de seu aprendizado teatral, já que os últimos capítulos são dedicados a contar as experiências do protagonista - sua compreensão da vida e da situaçáo cultural de seu tempo - depois que ele deixa para trás a companhia de teatro e se envolve com um círculo social misterioso. Mas Lukács avalia que o tratamento dado por Goethe para a "questão shakespeariana" como parte do processo de formação ultrapassa em muito a esfera do gênero dramático e mesmo da poética, já que Shakespeare era considerado pelo escritor como "um grande educador para uma humanidade e personalidade totalmente desenvolvidas" (Ibid., p. 583). Com isso, seus dramas seriam vistos como "modelos do modo como o desenvolvimento da

\footnotetext{
${ }^{18}$ Lukács, Posfácio, em: Goethe, 1994, p. 58I.
} 
personalidade atingiu a plenitude nos grandes períodos do humanismo e de como esse desenvolvimento deveria se completar no presente".

$\mathrm{Na}$ história, Wilhelm Meister sente, em seus esforços teatrais para encenar Hamlet, o quanto Shakespeare se estende para além dos limites do palco, evidenciando assim que a peça está intrinsecamente ligada ao modo como o processo de formação é pensado por Goethe. Sendo um ponto de transição, o teatro faria parte do complexo desenvolvimento da personalidade e da humanização no mundo moderno, mas a verdadeira descrição crítica da sociedade desse período viria na forma do romance.

Essa ideia, segundo Lukács, é explicitada na estética de Hegel, que já apontava para o nascimento do romance ligado ao predomínio da prosa sobre a poesia, da realidade prosaica sobre a fantasia poética. A partir da referência do Dom Quixote, o filósofo alemão diagnosticava que "o romanesco é o cavalheiresco que se torna novamente sério" (Ibid., p. 593). ${ }^{19}$ Como, no mundo moderno que se desenvolveu desde a época de Cervantes e Shakespeare (dois escritores contemporâneos), a existência exterior ganhou a forma rígida do Estado e da sociedade burguesa, os objetivos quiméricos do cavaleiro medieval dáo lugar à polícia, aos tribunais, ao exército. Com isso, os heróis que atuam nos romances modernos passariam a ser contrapostos, "enquanto indivíduos, com suas metas subjetivas de amor, honra, ambição, ou com seus ideais de aprimoramento do mundo, a essa ordem subsistente à prosa da realidade que lhes obsta por todas as partes o caminho" (Ibid.). Para caracterizar essas lutas do indivíduo contra a ordem rígida da sociedade, Hegel alude claramente a Goethe ao fazer uso da expressão "anos de aprendizado", durantes os quais o sujeito aprende com a experiência.

Segundo as teorias do romance elaboradas desde Hegel, não é à toa que o protagonista da obra de Goethe tenha como referência Hamlet, um herói trágico que, a partir da imposição de um dever social e político, constatava que o tempo estava fora de eixo e lamentava sua sina de ter de consertá-lo. Indivíduo isolado e aprisionado pelas circunstâncias, ele parece se reconhecer como personagem de um drama que ele mesmo precisará alterar, ao longo de uma trajetória que impóe também a transformação e o remodelamento de seu próprio caráter. Já que, conforme afirma Bakhtin a partir da noção hegeliana, um dos temas básicos do romance é precisamente o tema da inadequaçáo do personagem em relação ao seu destino e à sua

\footnotetext{
${ }^{19}$ Cf, Hegel, 20I4, "O romanesco", p. 328.
} 
situação, Hamlet pode ser visto como um protótipo para personagens como Wilhelm Meister, Werther e muitos outros protagonistas romanescos que marcaram a produção literária desde o final do século dezoito. ${ }^{20}$

\section{Referências bibliográficas}

Auerbach, E. (1976). Mimesis. São Paulo: Perspectiva.

Bate, J. (1992). The romantics on Shakespeare. London: Penguin books.

Bakhtin, M. (20I5). Teoria do romance I. Tradução de Paulo Bezerra. São Paulo: Editora 34.

Bakhtin, M. (20I8). Teoria do romance II. Tradução de Paulo Bezerra. São Paulo: Editora 34 .

Bakhtin, M. (2019). Teoria do romance III: O romance como gênero literário. São Paulo: Editora 34.

Bakhtin, M. (20I6). Os gêneros do discurso. Tradução de Paulo Bezerra. São Paulo: Editora 34 .

Benjamin, W. (20II). Origem do drama trágico alemão. Tradução de João Barrento. Belo Horizonte: Autêntica.

Benjamin, W. (1999). O conceito de crítica no Romantismo alemão. Tradução de Márcio Seligmann-Silva. São Paulo: Iluminuras.

Bradley, A. C. (2009) A tragédia shakespeariana. Tradução de Alexandre Feitosa Rosa. São Paulo: Martins Fontes.

Eliot, T. S. (1927). Shakespeare and the stoicism of Seneca. London: Oxford University Press.

Eliot, T. S. (20I5). "Hamlet e seus problemas", em Shakespeare. Hamlet. Tradução de Lawrence Flores Ferreira. São Paulo: Penguin e Companhia das Letras.

Ésquilo. (1990). Oréstia. Tradução de Mario da Gama Kury. Rio de Janeiro: Zahar.

Freud, S. (196I). Die Traumbedeutung. Gesammelte Werke, II/III. Frankfurt: Fischer Verlag.

Freud, S. (20I8). A interpretação dos sonhos. Tradução Walderedo Ismael de Oliveira. 2o. ed. Rio de Janeiro: Nova Fronteira. [livro eletrônico]

Goethe, J. (1993). Werke in sechs Banden. Frankfurt: Insel Verlag.

Goethe, J. (1994). Os anos de aprendizado de Wilhelm Meister. São Paulo: Ensaio.

Goethe, J. (2000). Escritos sobre literatura. Rio de Janeiro: 7 letras.

Goethe, J \& Schiller, F. (1993). Goethe e Schiller: Companheiros de Viagem. Tradução de Cláudia Cavalcanti. São Paulo: Nova Alexandria.

Goethe, J \& Schiller, F. (1977). Der Briefwechsel zwischen Goethe und Schiller. Frankfurt: Insel Verlag.

\footnotetext{
${ }^{20}$ Bakhtin, 2019, p. I07.
} 
Greenblatt, S. (20II). Como Shakespeare se tornou Shakespeare. São Paulo: Cia. das Letras.

Greenblatt, S. (200I). Hamlet in Purgatory. Princeton: Princeton University Press.

Hazlitt. (2008). "Hamlet". In: Bloom_(Org). Bloom's Shakespeare through the ages. Hamlet. New York: Infobase Publishing.

Hegel, G. W. F. (2000). Cursos de estética I. Tradução de Marco Aurélio Werle. São Paulo: Edusp.

Hegel, G. W. F. (2004)._Cursos de estética IV. Tradução de Marco Aurélio Werle. São Paulo: Edusp.

Hegel, G. W. F. (20I4). Cursos de estética II. Tradução de Marco Aurélio Werle e Oliver Tolle. São Paulo, Edusp.

Hegel, G. W. F. (1986). Werke [in 20 Bänden]. Frankfurt am Main: Suhrkamp.

Johnson, S. (1996) Prefácio a Shakespeare. Tradução de Enid Abreu Dobránsky. São Paulo: Iluminuras.

Kottman, P. A. (Org). (2009). Philosophers on Shakespeare. Standord: Stanford University Press.

Lacan, J. (2016). O desejo e sua interpretação (Seminário 6: 1958-1959). Texto estabelecido por Jacques-Alain Miller. Tradução de Claudia Berliner. Rio de Janeiro: Zahar.

Lukács, G. (1968) Ensaios sobre literatura. Tradução de Roberto Franco de Almeida. Rio de Janeiro: Civilização Brasileira.

Lukács, G. (2015). A alma e as formas. Tradução de Rainer Patriota. Belo Horizonte: Autêntica.

Lukács, G. (2000). A teoria do romance. Tradução de José Marcos Mariani de Macedo. São Paulo: Editora 34.

Medeiros, F. (2015). "Shakespeare, cultura retórica e modernidade: um comentário sobre Coriolano (I608)”. In: Berutti, Eliane B. (Org.). Feminismos, identidades, comparativismos: vertentes nas literaturas de lingua inglesa. Rio de Janeiro: Letra Capital, v. I3, p. 37-5I.

Nuttall, A. D. (2007). Shakespeare, the thinker. New Haven and London: Yale University Press

Schlegel, A. W. (20I8). Vorlesungen über dramatische Kunst und Literatur [I809-I8II] Herausgegeben und kommentiert von Stefan Knödler. Erster Teil. Paderborn: Ferdinand Schöningh.

Schlegel, A. W. (1846). August Wilhelm von Schlegels sämmtliche Werke. Hrsg. v. Eduard Böcking, Leipzig, Weidmann'sche Buchhandlung, sechster Band.

Schlegel, A. W. (1962). Kritische Schriften und Briefe. Stuttgart: Kohlhammer. 
Schlegel, A. W. (2006). "Algumas observaçóes sobre William Shakespeare por ocasião do Wilhelm Meister”. Tradução de Natália Giosa Fujita. Dissertação apresentada ao Programa de Pós-Graduação em História da Filosofia, do Departamento de Filosofia da Faculdade de Filosofia, Letras e Ciências Humanas da Universidade de São Paulo, para obtenção do título de Mestre em Filosofia.

Schlegel, F. (2016). Fragmentos sobre poesia e literatura. Tradução de Constantino Luz de Medeiros e Márcio Suzuki. São Paulo: Editora Unesp.

Schlegel, F. (1906). Seine prosäischen Jugendschriften. 2 Bde. E. Jakob Minor. Viena: Konegan.

Shakespeare, W. (2008). Hamlet. Cambridge University Press.

Shakespeare, W. (1987). Hamlet. Oxford University Press.

Shakespeare, W. (2015). Hamlet. Tradução de Lawrence Flores Ferreira. São Paulo: Penguin e Companhia das Letras.

Shakespeare, W. (2005). Hamlet. Tradução de Millôr Fernandes. Porto Alegre: LP.

Shakespeare, W. (2010). O primeiro Hamlet in-quarto de I603. Tradução de José Roberto O'Shea. São Paulo: Hedra.

Shakespeare, W. (1998). Four great tragedies. Nova York: Signet Classic.

Steiner, G. (2006). A morte da tragédia. Tradução de Isa Kopelmann. São Paulo: Perspectiva.

Szondi, P. (1978). Versuch über dem Tragishen. In: Schriften. Frankfurt: Suhrkamp.

Szondi, P. (2004). Ensaio sobre o trágico. Rio de Janeiro: Zahar.

Szondi, P. (200I). Teoria do drama moderno. São Paulo: Cosac Naify.

Szondi, P. (1974). Poetik und Geschichtsphilosophie I. Studienausgabe der Vorlesungen Band 2. Frankfurt am Main: Suhrkamp Verlag.

Werle, M. A. (2005). A poesia na estética de Hegel. São Paulo: Associação Editorial Humanitas.

Werle, M. A. (20I3). "Teatro, formación y vida en el Wilhelm Meister de Goethe”. Estudios de filosofía, n. 47, pp. I07-II9.

Werle, M. A. (20I7). "A dimensão filosófica do Meister de Goethe e do Gato Murr de Hoffmann", Discurso, Revista do Departamento de Filosofia da USP, v. 47, n. I, pp. 283-306. 